2

I N S A N

\title{
Pengaruh Regulasi Diri terhadap Motivasi Berprestasi pada Mahasiswa Penerima Bantuan Bidikmisi di Universitas Airlangga
}

\author{
ADDIENA HAFIDZA NURILLAH \& ACHMAD CHUSAIRI* \\ Departemen Psikologi Kepribadian dan Sosial, Fakultas Psikologi Universitas Airlangga
}

\begin{abstract}
ABSTRAK
Remaja yang tumbuh dengan kondisi kemiskinan seringkali dikaitkan dengan perkembangan yang maladaptif. Mahasiswa Bidikmisi sebagai remaja dari keluarga miskin yang mampu bangkit dan memiliki prestasi di bidang akademik adalah sebuah kasus yang menarik untuk dipelajari. Penelitianpenelitian sebelumnya mengenai prestasi akademik yang dimiliki mahasiswa Bidikmisi banyak dikaitkan dengan motivasi berprestasi. Usaha pencapaian prestasi tak luput dari kemampuan individu dalam meregulasi dirinya demi mencapai tujuan yang diinginkan. Penelitian ini memiliki fokus untuk mencari tahu pengaruh dari tingkat regulasi diri yang dimiliki mahasiswa Bidikmisi terhadap motivasi berprestasi. Data didapatkan dengan metode survei menggunakan kuesioner berisi skala Regulasi Diri dan skala Motivasi Berprestasi yang disusun sendiri oleh peneliti dengan sampel sebanyak 294 mahasiswa Bidikmisi angkatan 2018 di Universitas Airlangga. Hasil dari penelitian ini menunjukkan bahwa tingkat regulasi diri memiliki pengaruh secara positif terhadap motivasi berprestasi yang dimiliki mahasiswa Bidikmisi di Universitas Airlangga.
\end{abstract}

Kata kunci: bidikmisi; motivasi berprestasi; regulasi diri

\begin{abstract}
Adolescents grown with poverty conditions are often associated with maladaptive development. Bidikmisi students are adolescents with economically disadvantaged family background whom is resilient and able to achieve academic excellence, thus interesting to be studied further. Previous studies about Bidikmisi students' academic achievement are often associated with achievement motivation. The effort to achieve is manifested from one's ability to self-regulate in order to achieve the desired goal. The aim of this study was to find out the influence of Bidikmisi students' level of self-regulation towards their achievement motivation. The data was collected with a survey method using a questionnaire containing a self-developed self-regulation scale and achievement motivation scale with a sample of 294 Airlangga University's Bidikmisi students 2018 class. The results shown that the level of self-regulation positively influenced Airlangga University's Bidikmisi students' achievement motivation.
\end{abstract}

Keywords: achievement motivation; bidikmisi; self-regulation 
INSAN Jurnal Psikologi dan Kesehatan Mental, 2018, Vol. 3(2), pp, doi: 10.20473/jpkm.v3i22018.62-72 Dikirimkan: 16 Oktober 2019 Diterima: 10 Desember 2019 Diterbitkan: 26 Februari 2020 Editor: Rizqy Amelia Zein

*Alamat korespondensi: Fakultas Psikologi Universitas Airlangga, Jalan Airlangga 4-6 Surabaya 60286. Pos-el: achmad.chusairi@psikologi.unair.ac.id

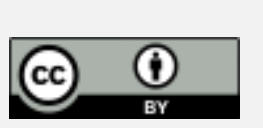

Naskah ini merupakan naskah dengan akses terbuka dibawah ketentuan the Creative Common Attribution License (http://creativecommons.org/licenses/by/4.0), sehingga penggunaan, distribusi, reproduksi dalam media apapun atas artikel ini tidak dibatasi, selama sumber aslinya disitir dengan baik.

\section{P E N D A H U L U A N}

Indonesia adalah negara dengan jumlah populasi terbesar nomor empat di dunia (Central Intelligence Agency, 2017) dengan angka kemiskinan mencapai 9,82\% atau sebanyak 25,95 juta jiwa dari total perkiraan jumlah penduduk di Indonesia 265 juta jiwa (Badan Pusat Statistik, 2018). Individu yang tumbuh dalam kondisi kemisikinan akan memiliki resiko untuk mengalami rasa tidak berdaya sehingga dapat mengganggu kesejahteraan psikologis seperti memiliki persepsi diri yang negatif, merasa inferior, tertekan, kurang percaya diri, atau bahkan dapat berakhir dengan depresi (Lever, Pinol, \& Uralde, 2005). Kemiskinan juga menyebabkan stres serta memiliki kondisi afek negatif yang dapat menjadikan seseorang memiliki kemampuan pengambilan keputusan yang cenderung hanya berjangka pendek, menghindari resiko, cenderung membatasi diri untuk tidak melakukan hal-hal diluar kebiasaan, dan mengorbankan tujuan yang ingin dicapai (Haushofer \& Fehr, 2014). Remaja dengan kondisi perkembangan perubahan biologis maupun dampaknya terhadap kondisi psikologisnya apabila tumbuh dalam kondisi keluarga yang miskin akan memiliki stresor yang lebih daripada remaja yang hidup dengan kondisi ekonomi yang lebih beruntung (Wadsworth \& Compass, 2002).

Salah satu penyebab kemiskinan adalah rendahnya tingkat pendidikan serta kurangnya keterampilan yang dimiliki untuk memperoleh penghasilan dalam memenuhi kebutuhan hidup (Itang, 2017). Di daerah Jawa Timur, angka partisipasi kasar pendidikan di jenjang perguruan tinggi pada tahun 2016 hanya mencapai $28,13 \%$ atau setara dengan 1,3 juta penduduk, dan lebih dari separuhnya merupakan masyarakat yang berasal dari golongan ekonomi kelas menengah keatas (Badan Perencanaan Pembangunan Nasional, 2016). Terbatasnya akses terhadap pendidikan dapat disebabkan oleh tingginya biaya pendidikan perguruan tinggi di Indonesia (CNBC Indonesia, 2018). Untuk mengurangi kesenjangan tersebut kemudian pemerintah Indonesia menyediakan program bantuan dana pendidikan di jenjang perguruan tinggi untuk individu-individu dari keluarga miskin yang memiliki reputasi akademik baik yang disebut dengan program Bidikmisi (Ristekdikti, 2018; Sekretariat Kabinet Republik Indonesia, 2018).

Universitas Airlangga (UNAIR) sebagai salah satu perguruan tinggi terbaik (QS Quacquarelli Symonds, 2014) telah menerima setidaknya tiga ribu lima ratus mahasiswa Bidikmisi sejak tahun 2015 hingga 2018. Mahasiswa Bidikmisi memiliki capaian prestasi akademik yang lebih baik dibandingkan dengan mahasiswa non-Bidikmisi apabila diukur dari capaian indeks prestasi kumulatif yang dimiliki (Retnaningtyas, 2017; Sucahyo \& Muhammad, 2014; Yusliana, 2015). Seorang anak dianggap resilien dalam kondisi stres akibat kemiskinan apabila mampu memperoleh nilai yang baik di sekolah, memiliki pandangan yang positif terhadap dirinya, serta mampu berperilaku prososial (Masten \& Coatsworth, 1998). Mahasiswa Bidikmisi menjadikan keunggulan akademik sebagai cara untuk meningkatkan rasa percaya diri sehingga mampu untuk membentuk identitas diri yang positif (Chusairi, 2017). Hal ini berseberangan dengan anggapan-anggapan mengenai perkembangan remaja yang terpapar kemiskinan 
yang cenderung melakukan hal-hal yang beresiko dan juga cenderung mengalami permasalahan akademis seperti misalnya cenderung memiliki performa akademik yang rendah dan rentan putus sekolah (Gutman \& Midgley, 2000). Penyebab dari permasalahan tersebut adalah paparan stresor lingkungan fisik dan psikososial yang mengelilingi anak yang tumbuh dalam kondisi kemiskinan, seperti misalnya tempat tinggal yang kumuh, penuh konflik, permasalahan keluarga, hingga kondisi dimana anak tinggal terpisah dari orang tuanya (Evans \& Kim, 2013).

Agar dapat mencapai prestasi akademis yang diinginkan, maka mahasiswa Bidikmisi perlu untuk mempertahankan motivasinya untuk berprestasi atau biasa disebut dengan istilah motivasi berprestasi. Motivasi berprestasi dapat diartikan sebagai proses yang dapat menyebabkan seseorang untuk memiliki perilaku yang bertujuan untuk mencapai sebuah kriteria ataupun standar tertentu (Kaplan, 2008). Motivasi yang berasal dari kebutuhan terhadap sebuah pencapaian kemudian akan memunculkan dorongan-dorongan pada diri yang mampu menggerakkan seseorang untuk mencapai suatu standar keunggulan tertentu (McClelland, 1987). Motivasi berprestasi terbukti memiliki pengaruh yang signifikan terhadap prestasi akademik (Kuriyah, 2016; Sugiyanto, 2009) terutama dalam mempelajari kemampuan, strategi, serta perilaku baru (Pintrich \& Schunk, 2002). Hal ini dikarenakan oleh peran motivasi yang dapat menyebabkan seseorang akan lebih tertarik dalam mempelajari dan mengerjakan tugas yang diberikan (Seif, 2008).

Secara umum motivasi berpestasi yang dimiliki seseorang dapat dipengaruhi oleh faktor-faktor intrinsik seperti kemungkinan sukses yang ingin dicapai, efikasi diri, standar yang ditetapkan, ketakutan akan kegagalan, dan faktor ekstrinsik seperti hubungan dengan lingkungan keluarga, sekolah, dan juga teman sebaya (McClelland, 1987). Motivasi berprestasi didasari oleh dua hal, yakni harapan untuk sukses (hope of success) dan juga ketakutan akan kegagalan (fear of failure), sehingga individu akan terush berusaha untuk meningkatkan kemampuannya demi menghindari kegagalan (Cohen, 1976). Selain itu, terdapat enam determinan yang dapat menentukan arah motivasi seseorang untuk berprestasi, yaitu statusnya dengan para ahli, keinginan untuk memperoleh sesuatu yang tinggi (aquisitiveness), prestasi yang didapat secara mandiri, statusnya dengan teman sebaya, rasa kompetitif yang dimiliki (competitiveness), serta rasa kepedulian terhadap suatu keunggulan (concern for excellence) (Jackson, Ahmed, \& Heapy, 1976).

Berdasarkan wawancara awal yang dilakukan terhadap mahasiswa Bidikmisi angkatan 2018 di UNAIR, sebagai mahasiswa tahun pertama mereka menunjukkan bahwa motivasi untuk mencapai prestasi akademik cukup tinggi. Sebagaimana pula penelitian lain yang menyebutkan bahwa mahasiswa Bidikmisi angkatan 2018 di UNAIR memiliki tingkat motivasi berprestasi yang tinggi (Rozaldi, 2019). Peneliti juga menemukan bahwa motivasi yang dimiliki oleh mahasiswa Bidikmisi berasal dari harapan untuk sukses demi membantu meningkatkan perekonomian keluarganya.

Di sisi lain, hasil dari wawancara awal juga menunjukkan bahwa setelah menjalani kehidupan perkuliahan selama satu semester, mahasiswa Bidikmisi 2018 merasa mencapai target yang diinginkan bukanlah hal yang mudah. Hal ini dapat disebabkan oleh adanya penyesuaian diri yang harus dilakukan oleh mahasiswa tingkat pertama dalam berbagai aspek kehidupannya (Rosiana, 2011; Nurfitriana, 2016). Kesuksesan dalam melakukan penyesuaian diri memiliki hubungan yang erat dengan kemampuan seseorang dalam meregulasi dirinya, semakin baik kemampuan regulasi diri yang dimiliki, maka akan semakin baik pula penyesuaian diri yang dilakukan (Isnaini, 2017; Wulan \& Negara, 2018). Namun demikian terdapat temuan bahwa individu yang tumbuh dalam lingkungan keluarga yang miskin, akumulasi dari stressor lingkungan fisik maupun psikososial dapat menyebabkan terganggunya proses-proses regulasi diri yang dapat membantu seseorang untuk mengatasi tuntutan-tuntutan eksternal yang diterima selama melakukan penyesuaian diri (Evans \& Kim, 2013). 
Motivasi berprestasi dapat pula dipengaruhi oleh kemampuan regulasi diri yang dimiliki (Apranadyanti, 2010; Doostian, dkk., 2014; Langley \& Bart, 2008). Regulasi diri mengatur hampir seluruh perilaku manusia yang memiliki tujuan tertentu. Regulasi diri adalah sebuah proses kognitif yang terjadi secara simultan yang melibatkan proses observasi diri, penilaian diri, dan respon terhadap diri (Bandura, 1991). Regulasi diri merupakan salah satu kunci keberhasilan dalam mencapai tujuan, seseorang yang memeiliki kemampuan regulasi diri yang baik akan mampu untuk memunculkan motivasi dirinya untuk mencapai tujuan yang diinginkan (Ormrod, 1995). Individu yang memiliki motivasi dan menggunakan strategi metakognisi dan regulasi diri dalam urusan akademis akan membuat progres yang lebih baik (Kuyper, Van der Werf, \& Lubbers, 2000) dan pelajar yang mampu meregulasi dirinya akan memiliki motivasi yang lebih baik untuk mencapai tujuan di masa depan (Miller \& Brickman, 2004).

Regulasi diri dipengaruhi oleh faktor individu, faktor perilaku, dan juga faktor lingkungan (Zimmerman, 2000). Dimana dalam faktor individu, pengetahuan dan tingkat kemampuan metakognisi serta tujuan yang ingin dicapai akan dicapai akan menentukan bagaimana individu akan menggunakan pengetahuan serta kemampuan metakognisi yang dimiliki. Dalam faktor perilaku, apabila perilaku yang ditunjukkan mengacu pada upaya untuk menggunakan seluruh kemampuan yang dimiliki dalam mengorganisir suatu aktivitas, maka semakin tinggi pula regulasi diri yang ada pada diri individu. Sementara pada faktor lingkungan, jika lingkungannya optimal dan tidak terlalu mengatur dalam memberikan kebebasan untuk bertindak dalam mencapai tujuan, maka individu akan lebih mudah untuk mengatur regulasi dirinya agar lebih optimal (Pintrich, 2000). Selain itu, bagaimana orang-orang terdekat bereaksi terhadap perilaku yang ditunjukkan dan bagaimana individu menjadikan orang lain sebagai patokan standarnya, dan juga bagaimana kesamaan nilai-nilai dan dukungan yang bersifat mutual mampu memengaruhi standar dalam proses penilaian diri (Bandura, 1991).

Dengan banyaknya jumlah mahasiswa Bidikmisi yang harus dibina oleh UNAIR, maka perlu adanya perhatian khusus sehingga tujuan dari program Bidikmisi dapat tercapai dengan baik. Selain itu, adanya temuan yang berseberangan antara tingkat motivasi berpretasi dan juga regulasi diri pada individu yang terpapar kemiskinan dan juga kasus mahasiswa Bidikmisi, peneliti kemudian tertarik untuk mencari tahu apakah regulasi diri dapat memengaruhi motivasi berprestasi pada mahasiswa Bidikmisi di UNAIR.

\section{ME T O D E}

\section{Partisipan}

Subjek dalam penelitian ini adalah 294 mahasiswa aktif angkatan 2018 di Universitas Airlangga yang merupakan penerima bantuan bidikmisi $(\mathrm{L}=41, \mathrm{P}=253)$ dengan rentang usia 16-19 tahun ( $m e a n=18,41$; $\mathrm{SD}=0,569)$. Peneliti menentukan batas usia bawah 16 tahun untuk mengantisipasi adanya mahasiswa yang merupakan lulusan program percepatan/akselerasi di tingkat sekolah ataupun memulai sekolah lebih awal dari usia pada umumnya.

\section{Prosedur}

Penelitian ini menggunakan pendekatan kuantitatif dengan desain penelitian survei. Pengambilan data dilakukan selama 20 hari dengan menyebarkan kuesioner dalam bentuk online melalui Google Form kepada mahasiswa Bidikmisi 2018. Atas izin Direktorat Kemahasiswaan serta organisasi mahasiswa bidikmisi (AUBMO) di Universitas Airlangga yang menaungi mahasiswa bidikmisi di Universitas Airlangga peneliti mendapatkan izin untuk mengakses database penerima bantuan bidikmisi di UNAIR tahun 2018 dan juga kontak koordinator mahasiswa bidikmisi di seluruh jurusan dan fakultas di UNAIR. Penyebaran kuesioner dilakukan dengan cara membagikan pesan secara berantai melalui koordinator 
mahasiswa bidikmisi di setiap jurusan maupun fakultas yang ada di UNAIR dengan memperhatikan kesediaan subjek untuk mengisi kuesioner. Karena hasil yang didapatkan dari pesan berantai tidak memenuhi jumlah minimum sampel, peneliti harus menyebarkan kuesioner melalui komunikasi personal melalui aplikasi "WhatsApp" berdasarkan database yang telah diperoleh dari Direktorat Kemahasiswaan UNAIR hingga mampu memperoleh jumlah yang sesuai dengan kebutuhan peneliti.

\section{Pengukuran}

Data penelitian didapatkan melalui penggunaan skala regulasi diri (reliabilitas 0,865) dan skala motivasi berprestasi (reliabilitas 0,888 ) yang disusun sendiri oleh peneliti berdasarkan konsep regulasi diri Albert Bandura (1991) dan konsep motivasi berpestasi David McClelland (1987) dengan model skala Likert dengan empat pilihan jawaban yakni "Sangat Sesuai”, "Sesuai”, "Tidak Sesuai”, "Sangat Tidak Sesuai" (SS-S-TS-STS).

Analisis data

Data yang didapatkan kemudian diolah dengan menggunakan uji statistik regresi terhadap kedua variabel dengan bantuan aplikasi pengolah data statistik SPSS versi 25.

\section{H A S I L P EN ELIT IAN}

Tabel 1. Analisis Deskriptif Variabel Penelitian

\begin{tabular}{ccc}
\hline & Regulasi Diri & Motivasi Berprestasi \\
\hline N & 294 & 294 \\
Rata-rata & 71,97 & 72,80 \\
Standar Deviasi & 7,260 & 7,724 \\
Range & 49 & 48 \\
Skewness & $-0,306$ & 0,023 \\
Standard Error (SE) Skewness & 0,142 & 0,142 \\
Kurtosis & 1,398 & 1,210 \\
Nilai Minimum & 39 & 44 \\
Nilai Maksimum & 88 & 92 \\
\hline
\end{tabular}

Selain itu, peneliti juga menambahkan analisis deskriptif usia untuk mengetahui karakteristik sampel berdasarkan usianya. Hasilnya diperoleh bahwa dari 294 sampel, sesuai dengan kriteria subjek usia minimum sampel adalah 16 tahun dan maksimum 19 tahun, dengan rata-rata atau mean usia 18,41, dan standar deviasi atau $S D$ usia 0,569.

Pengujian hipotesis dilakukan menggunakan analisis regresi, namun sebelumnya perlu untuk melakukan uji asumsi normalitas residual data serta serta uji homoskedasdisitas data. Dimana dalam uji normalitas data dilakukan dengan meilhat persebaran residual data, diketahui bahwa pola persebarannya mengikuti garis dan tidak terdapat outlier data yang harus dieliminasi. Sementara dalam uji homoskedasdisitas data diperlukan untuk mengetahui apakah model regresi yang dihasilkan memiliki kesamaan varians yang tetap dari satu pengamatan ke pengamatan lainnya atau justru berubah-ubah. Hasil dari pengamatan pola persebaran titik ditemukan pola yang menyebar, sehingga dapat dikatakan bahwa persebaran data tidak mengalami gejala heteroskedasdisitas.

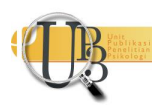


Uji korelasi terhadap kedua variabel menunjukkan bahwa terdapat hubungan yang kuat dengan arah positif antara kedua variabel $(r(294)=0.738, p=0,000)$, yang berarti bahwa semakin tinggi tingkat regulasi diri yang dimiliki maka semakin tinggi pula motivasi berprestasi yang dimiliki mahasiswa Bidikmisi.

Hasil analisis regresi linear diketahui bahwa regulasi diri berkorelasi positif dengan motivasi berprestasi $(B=0,816 ; S E=0,044 ; t=18,679 ; p<0,000)$. Sehingga dalam penelitian ini Hipotesis alternatif diterima, yakni terdapat pengaruh dari variabel regulasi diri terhadap motivasi berprestasi pada mahasiswa Bidikmisi Universitas Airlangga. Nilai koefisien variabel regulasi diri terhadap motivasi berprestasi adalah sebesar 0,544 atau 54,4\%, sehingga 45,6\% lainnya adalah pengaruh dari variabel lain yang tidak diukur dalam penelitian ini. Model regresi untuk analisis regresi linier yang dihasilkan dari penelitian ini adalah $\left(F(294)=348,921, P<0,000, R^{2}=0,544\right)$.

\section{I S K US I}

Tujuan dari penelitian ini adalah untuk mengetahui pengaruh dari regulasi diri terhadap motivasi berprestasi pada mahasiswa Bidikmisi di Universitas Airlangga. Sebagai remaja yang mampu memenuhi indikator dalam perkembangan remaja positif, mahasiswa Bidikmisi adalah remaja dalam kondisi kemiskinan yang mampu menjadikan dirinya pemutus lingkaran kemiskinan yang seringkali dikaitkan dengan ketidakmampuan membentuk identitas diri yang positif. Mahasiswa Bidikmisi menjadikan prestasi akademik sebagai aset diri yang dapat membantu mereka mengkonstruksikan diri secara positif (Chusairi, 2017). Dalam mengejar prestasi akademik, motivasi berprestasi memiliki peranan yang penting karena dapat memengaruhi tingkat ketertarikan seseorang dalam mempelajari serta mengerjakan tugas yang harus dikerjakan secara sungguh-sungguh (Seif, 2008). Jika dilihat dari hasil perolehan skor, mahasiswa Bidikmisi Universitas Airlangga memiliki tingkat motivasi berprestasi yang tinggi. Lebih dari 80\% sampel penelitian memiliki perolehan skor motivasi berprestasi dalam kategori tinggi.

Hasil dari analisis data penelitian ini menunjukkan bahwa regulasi diri memiliki hubungan yang positif terhadap motivasi berprestasi, serta regulasi diri memiliki pengaruh terhadap motivasi berprestasi sebesar 54,4\%. Hal ini mendukung penelitian yang dilakukan sebelumnya yang meneliti tentang hubungan regulasi diri dan motivasi berprestasi pada 74 siswa kelas X SMK Ibu Kartini Semarang. Hasil dari penelitian tersebut menunjukkan bahwa terdapat hubungan positif antara kedua variabel, dan motivasi berprestasi siswa kelas X di SMK Ibu Kartini Semarang juga dipengaruhi oleh regulasi diri sebesar 56,6\%. Maka, semakin tinggi regulasi diri maka semakin tinggi pula motivasi berprestasi yang dimiliki (Apranadyanti, 2010).

Begitu juga dengan penelitian semi-eksperimental yang dilakukan oleh Doostian dan rekan-rekannya pada tahun 2014 terhadap 84 siswa SMP tentang efektivitas regulasi diri pada motivasi berprestasi yang dimiliki oleh siswa. Siswa diajarkan kemampuan regulasi diri dalam delapan sesi dengan materi mengenai pentingnya regulasi diri serta manajemen waktu. Kemudian dilanjutkan dengan tahapantahapan regulasi diri, dimana siswa diajarkan cara untuk melakukan efisiensi diri, menentukan tujuan pribadi yang ingin dicapai, serta bagaimana caranya untuk mencapai tujuan tersebut dan implementasinya secara bertahap. Hasilnya menyebutkan bahwa siswa yang diajarkan kemampuan untuk meregulasi dirinya akan memiliki motivasi berprestasi yang lebih tinggi daripada yang tidak (Doostian, dkk., 2014).

Dasar dari motivasi berprestasi dapat terdiri dari dua hal, yakni harapan untuk sukses (hope of success) serta rasa takut akan kegagalan (fear of failure) (Cohen L. , 1976). Berdasarkan wawancara awal yang 
dilakukan peneliti, salah satu hal yang kemungkinan menyebabkan motivasi berprestasi tinggi pada mahasiswa Bidikmisi yaitu adanya keinginan untuk behasil menyelesaikan pendidikan dengan hasil memuaskan sehingga mampu memperoleh pekerjaan yang baik guna membantu perekonomian keluarganya. Temuan tersebut sejalan dengan penelitian terdahulu mengenai motivasi untuk berprestasi bagi anak yang tumbuh di keluarga miskin dengan budaya kolektivis seperti negara-negara di amerika latin, afrika, dan asia timur, bahwa anak diajarkan dan disiapkan untuk perannya memenuhi pencapaian yang sekiranya dapat mengangkat derajat atau membawa kehormatan bagi keluarganya (Bempechat, Graham, \& Jimenez, 1999). Budaya tersebut juga menjadikan orang tua di negara-negara ataupun keturunan Asia akan cenderung memupuk rasa malu dan rasa bersalah jika menemui kegagalan. Sehingga apabila mahasiswa Bidikmisi gagal dalam memenuhi ekspektasi orang tuanya, mereka akan mendapatkan tekanan dari rasa bersalah (guilt) ataupun rasa malu (shame) yang telah diajarkan oleh orang tuanya sejak dini.

Temuan lain dari penelitian ini adalah mahasiswa Bidikmisi UNAIR memiliki tingkat regulasi diri yang tinggi diantara kelompok. Sebagian besar sampel penelitian sebanyak 60,5\% memiliki kemampuan regulasi diri yang tinggi. Heckhausen dan Heckhausen menyebutkan bahwa ketika seseorang menunjukkan perilaku yang termotivasi, maka ia akan berusaha untuk mengontrol dan mengatur goal engagement dan goal disengagement (Heckhausen \& Heckhausen, n.a). Sehingga sebagian besar mahasiswa Bidikmisi akan mengatur strategi-strategi regulasi diri dalam usahanya mencapai prestasi akademis yang diinginkan.

Ada tiga faktor yang secara garis besar memengaruhi regulasi diri (Bandura, 1991), dari segi faktor individu dan perilaku, tujuan mahasiswa Bidikmisi dalam berusaha untuk lulus dengan nilai baik dan mendapatkan pekerjaan yang baik kemudian semakin meningkatkan kemungkinan bagi mereka untuk berusaha meregulasi dirinya. Adanya organisasi Bidikmisi AUBMO sebagai komunitas yang menaungi seluruh mahasiswa Bidikmisi di UNAIR serta peran aktif universitas dalam membina mahasiswa Bidikmisi juga turut memengaruhi standar mahasiswa Bidikmisi dalam proses penilaian diri saat meregulasi dirinya.

Pola perilaku meregulasi diri dalam rangka memotivasi diri untuk berprestasi ini kemudian menunjukkan bahwa perilaku mahasiswa Bidikmisi didasarkan pada tujuan yang telah ditetapkan di awal. Penetapan tujuan atau goal-setting melibatkan pembentukan sebuah rencana mengenai apa yang akan dilakukan, yang didesain untuk memotivasi dan menuntun seseorang menuju tujuan yang diinginkan (Grant, 2012). Hal ini penting untuk pengembangan diri, karena melibatkan penetapan tujuan dari performa yang dilakukan. Ketika seseorang memiliki tujuan yang jelas, ia telah mengetahui langkah-langkah apa yang harus dilakukan untuk mencapai tujuan tersebut, kemudian menentukan indikator-indikator capaiannya, dan juga standar untuk mengevaluasi capaiannya (Latham, 2012). Dengan demikian, individu tersebut akan lebih termotivasi dan terarah dalam bertindak mengatur sumberdaya serta kemampuan yang dimiliki demi tercapainya tujuan yang diinginkan.

Selain konsep-konsep yang telah dibahas dalam penelitian ini, terdapat banyak hal lainnya yang menarik untuk dikaji lebih lanjut pada remaja yang memiliki latar belakang kemiskinan. Pada domain perkembangan remaja positif, terdapat banyak aset pada remaja yang dapat dikaji lebih lanjut pada mahasiswa Bidikmisi yang merupakan contoh remaja yang dapat dianggap mampu berkembang secara positif. Seperti misalnya bagaimana mahasiswa Bidikmisi bergantung pada harapan untuk dapat meningkatkan kondisi perekonomian keluarganya yang dimiliki untuk tetap mempertahankan motivasi dirinya dalam mencapai dan mempertahankan keunggulan akademis yang dimiliki (Chusairi, 2017), bagaimana cara mahasiswa Bidikmisi untuk mengontrol diri mereka, dan mempertahankan efikasi diri yang dimiliki (Rozaldi, 2019), dan masih banyak lagi konstruk-konstruk yang dapat digali lebih dalam 
pada mahasiswa Bidikmisi, sehingga telaah yang dihasilkan dapat pula diterapkan pada individuindividu yang terpapar kemiskinan untuk membangun karakter diri yang positif.

\section{S I M P U L A N}

Hasil dari penelitian ini menunjukkan bahwa tingkat regulasi diri yang dimiliki oleh mahasiswa Bidikmisi dapat memberikan pengaruh terhadap motivasi berprestasi. Semakin tinggi tingkat regulasi diri yang dimiliki, maka semakin tinggi pula tingkat motivasi berprestasinya. Mahasiswa Bidikmisi adalah contoh kasus remaja yang mampu berkembang secara positif dan resilien meskipun terpapar kemiskinan yang telah memberikan sumber tekanan pada individu yang dapat menjadikan seseorang justru berkembang secara maladaptif.

Penelitian selanjutnya dapat menambahkan variabel demografis seperti latarbelakang pendidikan orang tua dan penghasilan orang tua untuk mengetahui pola perilaku regulasi diri dan motivasi berprestasi pada mahasiswa Bidikmisi. Selain itu, penggunaan pendekatan kualitatif untuk meneliti pengaruh dari regulasi diri maupun faktor-faktor lingkungan terhadap motivasi berprestasi mahasiswa Bidikmisi dapat pula digunakan. Sehingga dapat dihasilkan gambaran yang lebih luas dan jelas mengenai dinamika hal-hal yang dapat memengaruhi motivasi berprestasi dalam konteks mahasiswa Bidikmisi.

\section{U C A P A N T ERIMAKASIH}

Penulis berterima kasih kepada teman-teman penerima Beasiswa Bidikmisi di Universitas Airlangga yang telah menyediakan waktunya untuk berpartisipasi dalam penelitian ini sehingga penelitian dapat terselesaikan dengan baik.

\section{DEKLARASI POTENSI TERJADINYA KONFLIK KEPENTINGAN}

Addiena Hafidza Nurillah dan Achmad Chusairi tidak bekerja, menjadi konsultan, memiliki saham, atau menerima dana dari perusahaan atau organisasi mana pun yang akan mengambil untung dari naskah ini, dan telah mengungkapkan bahwa ia tidak memiliki afiliasi selain yang telah disebut di atas.

\section{PUST AKA ACUAN}

Apranadyanti, N. (2010). Hubungan Antara Regulasi Diri Dengan Motivasi Berprestasi Pada Siswa Kelas X SMK Ibu Kartini Semarang. Skripsi: Fakultas Psikologi Universitas Diponegoro, Semarang.

Badan Perencanaan Pembangunan Nasional. (2016). Data Statistik. Retrieved Oktober 27, 2018, from Kementerian PPN/ Bappenas: https://www.bappenas.go.id/id/data-dan-informasiutama/data-dan-statistik1/sumber-daya-manusia-dan-kebudayaan/

Badan Pusat Statistik. (2018). Badan Pusat Statistik. Retrieved Oktober 25, 2018, from Badan Pusat Statistik: https://www.bps.go.id/

Bandura, A. (1991). Social Cognitive Theory of Self-Regulation. Organizational Behavior and Human Decision Processes, 248-287.

Bempechat, J., Graham, S. E., \& Jimenez, N. V. (1999). The Socialization of Achievement in Poor and Minority Students. Journal of Cross-Cultural Psychology, 30(2), 139-158. 
Central Intelligence Agency. (2017). Central Intelligence Agency. Retrieved Oktober 25, 2018, from The World Factbook: https://www.cia.gov/library/publications/the-worldfactbook/rankorder/2119rank.html

Chusairi, A. (2017). Konstruksi Identitas Diri Remaja Miskin: Analisis Diskursif Pada Mahasiswa Penerima Beasiswa Bidikmisi. Surabaya: Fakultas Psikologi Universitas Airlangga.

CNBC Indonesia. (2018, April 16). RI Masuk Daftar Negara Biaya Pendidikan Termahal di Dunia. Retrieved Oktober 27, 2018, from CNBC Indonesia: https://www.cnbcindonesia.com/lifestyle/20180416125235-33-11142/ri-masuk-daftarnegara-biaya-pendidikan-termahal-di-dunia

Cohen, L. (1976). Educational Research in Classroom and Schools: A Manual of Materials and Methods. San Francisco: Harper \& Row Publishers.

Doostian, Y., Fatahi, S., Goudini, A. A., A'zami, Y., Massah, O., \& Daneshmand, R. (2014). The Effectivenes of Self-Regulation in Students's Academic Achievement Motivation. Practice in Clinical Psychology, 2(4), 261-269.

Evans, G. W., \& Kim, P. (2013). Childhood Poverty, Chronic Stress, Self-Regulation, and Coping. Child Development Perspectives, 7, 43-48.

Grant, A. M. (2012). An Integrated Model Of Goal-Focused Coaching: An Evidence-Based Framework for Teaching and Practice. International Coaching Psychology Review, 146-165.

Gutman, L. M., \& Midgley, C. (2000). The Role of Protective Factors in Supporting the Academic Achievement of Poor African American Students During the Middle School Transition. Journal of Youth and Adolescence, 29(2), 223-248.

Haushofer, J., \& Fehr, E. (2014, may 23). On the Psyholocy of Poverty. Science, 344(6186), pp. 862-867.

Heckhausen, J., \& Heckhausen, H. (n.a). Cambridge University Press. Retrieved from www.cambridge.org: https://www.cambridge.org/0521852595

Isnaini, F. (2017). Hubungan Antara Regulasi Diri Dengan Penyesuaian Diri Santri Pondok Pesantren di Surakarta. Skripsi.

Itang. (2017, Januari). Faktor-faktor Penyebab Kemiskinan. Tazkiya, 16(01), 1-30. Retrieved Oktober 27, 2018, from http://jurnal.uinbanten.ac.id/index.php/tazkiya/article/view/206

Jackson, D. N., Ahmed, S. A., \& Heapy, N. A. (1976). Is achievement a unitary construct? Journal of Research in Personality, 1-21.

Kaplan, A. (2008). Achievement Motivation. In E. M. Anderman, Psychology of Classroom Learning: An Encyclopedia (pp. 13-17). Detroit: GALE Cengage Learning.

Kuriyah. (2016). Pengaruh Motivasi Berprestasi Terhadap Prestasi Mahasiswa Penerima Beasiswa Bidikmisi Jurusan FE-UM. Malang: Universitas Negeri Malang.

Kuyper, H., Van der Werf, M., \& Lubbers, M. (2000). Motivation, meta-cognition, and self-regulation as predictors of long-term educational attainment. Educational Research and Evolution, 181-205. 
Langley, S. R., \& Bart, W. M. (2008). Examining Self-Regulatory Factors that Influence the Academic Achievement Motivation of Underprepared College Students. Research and Teaching in Developmental Education, 25, 10-22.

Latham, G. P. (2012). Motivate Employee Performance Through Goal-Setting. In E. Locke, Handbook of Principles of Organizational Behavior: Indispensable Knowledge for Evidence-Based Management. Wiley.

Lever, J. P., Pinol, N. L., \& Uralde, J. H. (2005). Poverty, Psychological Resources and Subjective WellBeing. Social Indicators Research, 375-408.

Masten, A. S., \& Coatsworth, J. D. (1998). The Development of Competence in Favorable and Unfavorable Environments: Lessons From Research on Successful Children. American Psychologist, 227-238.

McClelland, D. C. (1987). Human Motivation. Cambridge: Cambridge University Press.

Miller, R. B., \& Brickman, S. J. (2004). A model of future-oriented motivation and self-regulation. Educational Psychology Review, 9-33.

Nurfitriana, P. (2016). Penyesuaian Diri Pada Mahasiswa Tahun Pertama di Fakultas Psikologi Universitas Muhammadiyah Surakarta. Skripsi.

Ormrod, J. E. (1995). Human Learning (Second ed.). New Jersey: Prentice-Hall.

Pintrich, P. R. (2000). The Role of Goal Orientation In Self-Regulated Learning. In M. Boakerts, M. Zeidner, \& P. R. Pintrich, Handbook Of Self-Regulation (pp. 451-502). San Diego, California: Academic Press.

Pintrich, P. R., \& Schunk, D. H. (2002). Motivation in Education. Englewood Cliffs: Prentice Halls.

QS Quacquarelli Symonds. (2014). Study in Indonesia / Top Universities. Retrieved Juli 13, 2019, from QS Top Universities: https://www.topuniversities.com/where-to-study/asia/indonesia/guide

Retnaningtyas, S. (2017). Perbedaan Motivasi Belajar dan Prestasi Akademik Antara Mahasiwa Bidikmisi dan Reguler di Fakultas Ilmu Pendidikan Universitas Negeri Malang. Malang, Jawa Timur: Universitas Negeri Malang. Retrieved Oktober 28, 2018, from http://karyailmiah.um.ac.id/index.php/ASP/article/view/58257

Ristekdikti. (2018, Januari). Panduan Bidikmisi 2018: Fitur Pendaftar. Jakarta.

Rosiana, D. (2011). Penyesuaian Akademis Mahasiswa Tingkat Pertama. Prosiding Seminar Nasional Penelitian dan PKM: Sosial, Ekonomi, dan Humaniora, 491-496.

Rozaldi, A. (2019). Pengaruh Efikasi Diri Terhadap Motivasi Berprestasi Pada Mahasiswa Bidikmisi Universitas Airlangga. Skripsi.

Seif, A. (2008). Modern Educational Psychology. Tehran: Doran Publication.

Sekretariat Kabinet Republik Indonesia. (2018, Agustus 17). Anggaran Pendidikan 2019 Rp 487,9 Triliun, Pemerintah Akan Beri Beasiswa Bagi 20 Juta Lebih Siswa. Retrieved Oktober 27, 2018, from Sekretariat Kabinet Republik Indonesia: http://setkab.go.id/anggaran-pendidikan-2019rp4879-triliun-pemerintah-akan-beri-beasiswa-bagi-20-juta-lebih-siswa/

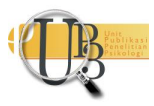


Sucahyo, A. Y., \& Muhammad, H. N. (2014). Perbandingan Prestasi Belajar Akademik Antara Mahasiswa Bidik Misi dan Mahasiswa Non Bidik Misi. Jurnal Pendidikan Olahraga dan Kesehatan, 02, 266268. Retrieved Oktober 28, 2018, from https://jurnalmahasiswa.unesa.ac.id/index.php/jurnalpendidikan-jasmani/article/viewFile/8233/8429

Sugiyanto. (2009). Kontribusi Motivasi Berprestasi Terhadap Prestasi Akademik Siswa Keals XI SMA Negeri 10 Semarang. Paradigma, 19-34.

Wadsworth, M. E., \& Compass, B. E. (2002). Coping With Economic Strain and Family Conflict: The Adolescent Perspective. Journal of Resilient Adolescence, 243-274.

Wulan, D. K., \& Negara, W. R. (2018, Oktober). Pengaruh Regulasi Diri Terhadap Penyesuaian Diri Pada Siswa Pondok Pesantren MA Husnul Khotimah. JPPP: Jurnal Penelitian dan Pengukuran Psikologi, $7(2), 99-93$.

Yusliana, S. (2015). Perbandingan Prestasi Akademik Mahasiswa Bidik Misi Dengan Mahasiswa Reguler Program Studi Pendidikan Geografi FKIP Unsyiah Tahun Akademik 2010/2011-2011/2012. Banda Aceh, Indonesia. Retrieved Oktober 28, 2018, from http://etd.unsyiah.ac.id/index.php?p=show_detail\&id=12991

Zimmerman, B. J. (2000). Attaining Self-Regulation: A Social Cognitive Perspective. In M. Boekaerts, P. R. Pintrich, \& M. Zeidner, Handbook of Self-Regulation (pp. 13-35). San Diego, CA: Academic Press. 